\title{
Landfill Leachate Treatment Using a Combination of Heterotrophic Denitrification and Partial Nitritation in a Single Sequencing Batch Reactor
}

\author{
Yanhong $\mathrm{Xu}^{1 *}$, Shaoqi Zhou ${ }^{2,4,5 *}$, Huosheng $\mathrm{Li}^{3}$ \\ ${ }^{1}$ School of Environmental Science and Engineering, Sun Yat-sen University, Guangzhou, China \\ ${ }^{2}$ College of Environment and Energy, South China University of Technology, \\ Guangzhou Higher Education Mega Center, China \\ ${ }^{3}$ Institute of Environmental Studies at Greater Bay, Key Laboratory for Water Quality and Conservation \\ of the Pearl River Delta, Ministry of Education, School of Environmental Science and Engineering, \\ Guangzhou University, Guangzhou, China \\ ${ }^{4}$ Guizhou Academy of Sciences, Guiyang, China
}

${ }^{5}$ State Key Laboratory of Subtropical Building Sciences, South China University of Technology, Guangzhou, China

Received: 8 October 2018

Accepted: 15 December 2018

\begin{abstract}
The combination of heterotrophic denitrification and partial nitritation for the treatment of landfill leachate was investigated in a single sequencing batch reactor with the objective of achieving simultaneous elimination of nitrogen and organic matter and providing a suitable effluent for the subsequent anaerobic ammonium oxidation (Anammox) treatment. Partial nitritation was established by finely adjusting the airflow rate (AFR) and the influent loading rate (ILR) to an oxygen-limiting condition. The long-term operation of the batch reactor showed that more than $55 \%$ removal of the chemical oxygen demand (COD) and 60\% elimination of total nitrogen (TN) were obtained. Cycle analysis showed that heterotrophic denitrification contributed to approximately $28 \%$ reduction of nitrogen and $24 \%$ reduction of COD in the bulk liquid. This study showed that the treatment capacity increased with the increasing total air flux (TAF), and that nitrate formation could be inhibited by controlling the ratio of TAF to ILR below $240\left(\mathrm{~m}^{3}\right.$ air $\mathrm{m}^{-3} / \mathrm{kg}$ COD$)$. It was also determined that the effluent $\mathrm{pH}$ was an indicator of the partial nitritation performance. This study provides important insights into the process control on partial nitritation of landfill leachate with fluctuated influent conditions.
\end{abstract}

Keywords: nitrogen removal, nitritation, landfill leachate, anammox, denitrification

*e-mail: xuyanhong87@163.com; zhousqgzas@163.com 


\section{Introduction}

Landfill leachate treatment is complicated because the leachate stream has high levels of ammonium and organic matter $[1,2]$. Conventional biological processes consisting of autotrophic nitrification and subsequent heterotrophic denitrification, have been shown to be effective in removing organic and nitrogenous matter $[3,4]$. However, the conventional nitrogen removal process is extremely expensive, as it requires tremendous oxygen consumption and the addition of an external organic carbon source $[5,6]$.

In the last decade, new techniques that utilize a combination of partial nitritation (PN) and anaerobic ammonium oxidation (anammox) [7-9], either in twostage systems or in the single reactor [10-12], have been developed to treat ammonium-rich wastewater more effectively $[13,14]$. Since most biodegradable organic fractions could negatively affect anammox performance [15], the one-stage PN/anammox process may only be applicable to wastewater with high levels of ammonium but lacking biodegradable organic carbon. The two-stage PN/anammox process, in which the PN precedes the anammox unit, is considered to have higher efficiency and reliability and stronger recovery performance [10]. Therefore, the two-stage PN/anammox processes may be more applicable and stable than the single reactor systems for the treatment of ammonium-rich organic wastewater.

The PN process, which requires control of the effluent with an $\mathrm{NO}_{2}{ }^{-} \mathrm{N} / \mathrm{NH}_{4}{ }^{+}-\mathrm{N}$ ratio of $1.32 / 1$ for the subsequent anammox treatment [16], reduces aeration by $64 \%$ and sludge production by $80-90 \%$ compared to conventional nitrification and denitrification processes $[17,18]$, creating substantial benefits for the treatment of highly nitrogenous wastewater $[19,20]$. Furthermore, the PN process can also remove the organic matter that may inhibit the anammox communities. This would provide a sustainable and feasible means for treating high-strength wastewater such as landfill leachate, which usually contains high concentrations of $\mathrm{NH}_{4}^{+}{ }^{+} \mathrm{N}$ and organic matter $[21,22]$.

There have been various studies completed on the PN process for the treatment of synthetic wastewater [23-25], digester liquor [26-29], black water [30], and underground brine waste [31], etc. In addition, some literature on the PN process for landfill leachate treatment [32-37] was available in recent years. It should be stated that these reports on the PN process for landfill leachate treatment were achieved through operation at high reaction temperatures of up to $30-36^{\circ} \mathrm{C}$, or short sludge retention time (SRT) below 12 days. In order to make this process simpler and more energy efficient, more operational conditions, such as lower reaction temperature and longer SRT, need to be investigated on the application of this process to landfill leachate treatment. In addition, more importance should also be attached to the elimination of organic matter present in the leachate. Combining heterotrophic denitrification in the PN treatment of landfill leachate may be a feasible option to simultaneously remove the organic carbon and nitrogen while reducing the treatment cost and possibly inhibiting readily available organic matter to subsequent anammox bacteria [38]. Taking into account the variation in the influent strength, its impact on the effluent $\mathrm{NO}_{2}^{-}-\mathrm{N} / \mathrm{NH}_{4}^{+}-\mathrm{N}$ ratio should also be addressed.

This work aims to combine the heterotrophic denitrification and partial nitritation for the treatment of landfill leachate in the single sequencing batch reactor in which room temperatures of $24.5-27.0^{\circ} \mathrm{C}$ and long SRT of 60-80 days were used. To gain more insight into the partial nitritation of landfill leachate, a cycle analysis of the dynamics of the various physicalchemical compounds was also performed. In addition, the process analysis on the reactor operation under variable influent compositions was also conducted in order to identify potential indicators to develop a realtime controlled PN system.

\section{Materials and Methods}

\section{Landfill Leachate Characteristics}

The raw leachate was obtained from a landfill in southern China that had been operating for 13 years. The leachate characteristics are listed in Table 1. The strength of the leachate was variable, which was likely caused by seasonal changes (from August to January). Ammonium $\left(\mathrm{NH}_{4}^{+}-\mathrm{N}\right)$, and organic matter account

Table 1. Main characteristics of landfill leachate used in different phases (Mean \pm Standard).

\begin{tabular}{|c|c|c|c|c|c|c|c|c|}
\hline Phases & $\begin{array}{l}\text { Operating periods } \\
\text { (Day) }\end{array}$ & $\mathrm{pH}$ & $\begin{array}{c}\text { Alkalinity } \\
\left(\mathrm{mg} \mathrm{CaCO}_{3} / \mathrm{L}\right)\end{array}$ & $\begin{array}{l}\text { COD } \\
(\mathrm{mg} / \mathrm{L})\end{array}$ & $\begin{array}{l}\mathrm{NH}_{4}^{+}-\mathrm{N} \\
(\mathrm{mg} / \mathrm{L})\end{array}$ & $\begin{array}{l}\mathrm{NO}_{2}-\mathrm{N} \\
(\mathrm{mg} / \mathrm{L})\end{array}$ & $\begin{array}{l}\mathrm{NO}_{3}^{-}-\mathrm{N} \\
(\mathrm{mg} / \mathrm{L})\end{array}$ & $\begin{array}{c}\mathrm{TN} \\
(\mathrm{mg} / \mathrm{L})\end{array}$ \\
\hline 1 & $1-49$ & $8.50 \pm 0.06$ & $\begin{array}{c}7491.70 \\
\pm 1896.12\end{array}$ & $\begin{array}{l}2234.75 \\
\pm 605.79\end{array}$ & $\begin{array}{c}854.22 \pm \\
207.16\end{array}$ & $0.57 \pm 0.40$ & $\begin{array}{l}12.61 \\
\pm 5.74\end{array}$ & $\begin{array}{r}975.96 \\
\pm 208.68\end{array}$ \\
\hline 2 & $50-109$ & $8.57 \pm 0.06$ & $\begin{array}{l}6373.16 \\
\pm 624.92\end{array}$ & $\begin{array}{l}2996.61 \\
\pm 490.33\end{array}$ & $\begin{array}{c}1108.20 \pm \\
85.28\end{array}$ & $0.68 \pm 0.19$ & $\begin{array}{l}15.63 \\
\pm 4.17\end{array}$ & $\begin{array}{l}1234.70 \\
\pm 82.35\end{array}$ \\
\hline 3 & $110-143$ & $8.56 \pm 0.10$ & $\begin{array}{l}6071.14 \\
\pm 399.68\end{array}$ & $\begin{array}{l}4180.55 \\
\pm 781.43\end{array}$ & $\begin{array}{l}1287.27 \\
\pm 107.67\end{array}$ & $0.79 \pm 0.27$ & $\begin{array}{l}27.09 \\
\pm 4.61\end{array}$ & $\begin{array}{l}1430.51 \\
\pm 106.01\end{array}$ \\
\hline 4 & $144-169$ & $8.49 \pm 0.07$ & $\begin{array}{l}9333.00 \\
\pm 731.72\end{array}$ & $\begin{array}{l}6914.55 \\
\pm 780.69\end{array}$ & $\begin{array}{l}1863.69 \\
\pm 121.18\end{array}$ & $1.39 \pm 0.61$ & $\begin{array}{l}49.68 \\
\pm 11.67\end{array}$ & $\begin{array}{l}2024.98 \\
\pm 126.67\end{array}$ \\
\hline
\end{tabular}


Table 2. Controlling parameters in different phases (Mean \pm Standard).

\begin{tabular}{|c|c|c|c|c|}
\hline Phases & $\begin{array}{c}\text { Operating periods } \\
\text { (Day) }\end{array}$ & Purpose & $\begin{array}{c}\text { Air flow rate } \\
\left(\mathrm{L}_{\text {air L }}^{-1} \text { reactor } \mathrm{h}^{-1}\right)\end{array}$ & $\begin{array}{c}\text { Volumetric exchange } \\
\text { ratio }(\%)\end{array}$ \\
\hline 1 & $1-49$ & Start-up of partial nitritation & $7.74 \pm 2.11$ & $19.27 \pm 11.17$ \\
\hline 2 & $50-109$ & $\begin{array}{c}\text { Maintenance of partial nitritation } \\
\text { under low influent concentration }\end{array}$ & $13.30 \pm 3.27$ & $31.17 \pm 3.43$ \\
\hline 3 & $110-143$ & $\begin{array}{c}\text { Maintenance of partial nitritation under } \\
\text { moderate influent concentration }\end{array}$ & $18.84 \pm 2.47$ & $31.68 \pm 3.02$ \\
\hline 4 & $144-169$ & $\begin{array}{c}\text { Maintenance of partial nitritation } \\
\text { under high influent concentration }\end{array}$ & $23.93 \pm 2.11$ & $23.24 \pm 4.07$ \\
\hline
\end{tabular}

for the major components of the leachate, and their concentrations were increasing overall during the experimental period, as shown in Table 1.

\section{Experimental Setup}

The total volume of the sequencing batch reactor (SBR) was $70 \mathrm{~L}$, and its actual working volume varied from $44.5 \mathrm{~L}$ to $51.5 \mathrm{~L}$, depending on the actual treatment capacity and performance. The reactor was operated at room temperatures of $24.5-27.0^{\circ} \mathrm{C}$ and in cycles of 12 hours. Each cycle consisted sequentially of 1-2 min of feed (depending on the treatment capacity), 90 min of anoxic stir, 270 min of concurrent aeration and stir, $60 \mathrm{~min}$ of anoxic stir, $240 \mathrm{~min}$ of concurrent aeration and stir, $55 \mathrm{~min}$ of settlement, and 3-4 min of draw (depending on the treatment capacity). The control of feed, stir, aeration, sludge wastage and draw was performed by a programmable logic controller (PLC). Specifically, the feed and draw were controlled by the float level switches connected to the PLC. The SRT was controlled at 60-80 days through wasting a certain amount of sludge liquid at the end of the second aeration stage. Air was supplied by the air compressor through the air diffusers mounted at the bottom of the reactor. The air flow rate (AFR) used in different phases is shown in Table 2. The dissolved oxygen (DO) and $\mathrm{pH}$ profiles of the sludge liquor were monitored with a multi-parameter water quality meter (Inolab multi 740, WTW, Germany), respectively. Forced pH adjustment and DO controls were not performed in order to make the operation simpler.

\section{Experimental procedure}

Prior to the start-up, $42 \mathrm{~L}$ of nitrifying activated sludge (mixed liquid suspended solids (MLSS) 2000 $\mathrm{mg} / \mathrm{L}$ ) from a full-scale SBR [39], which operated in the same landfill site treating landfill leachate, was inoculated in the reactor. The operation can be divided into four phases in terms of the influent compositions and the AFR used. The controlling parameters in different phases are listed in Table 2. Due to the fluctuation of DO in the bulk liquid, the AFR and the volumetric exchange ratio (VER) in each phase were utilized as the direct controlling factors. During the experiment, the
AFR was adjusted according to the observed influent loading rate (ILR) and treatment performance.

\section{Analytical Methods}

Samples were collected and analyzed regularly to evaluate the treatment performance. Measurements, including MLSS, mixed liquid volatile suspended solids (MLVSS), chemical oxygen demand (COD), sludge volumetric index (SVI), ammonium, nitrates, nitrites, total nitrogen (TN), and alkalinity, were taken according to standard methods [40]. As nitrite exerts a COD of $1.1 \mathrm{mg} \mathrm{O} / \mathrm{mg} \mathrm{NO}_{2}^{-}-\mathrm{N}$, the $\mathrm{COD}$ values were corrected accordingly. Free ammonia (FA) and free nitrous acid (FNA) concentrations in the effluent were calculated according to Anthonisen et al. [41]. The DO concentrations and the $\mathrm{pH}$ values were measured by a multi-parameter water quality meter (Inolab multi 740, WTW, Germany).

Nitrate percentage in the effluent was calculated according to Equation 1, where $C_{\text {eff. nitrite, }}, C_{\text {eff. nitrate }}$ were the concentrations $(\mathrm{mg} / \mathrm{L})$ of nitrite and nitrate nitrogen in the effluent, respectively.

$$
\text { Nitrate percentage }(\%)=\frac{C_{\text {eff. nitrate }}}{C_{\text {eff. nitrite }}+C_{\text {eff. nitrate }}} \times 100 \%
$$

The influent loading rate (ILR) $\left(\mathrm{kg} \mathrm{COD} / \mathrm{m}^{3} / \mathrm{d}\right)$ was defined as the sum of oxygen demand from the influent COD loading rate (CLR) $\left(\mathrm{kg} \mathrm{COD} / \mathrm{m}^{3} / \mathrm{d}\right)$ and from the partial nitritation portion of influent ammonium loading rate (ALR) $\left(\mathrm{kg} \mathrm{NH}_{4}^{+}-\mathrm{N} / \mathrm{m}^{3} / \mathrm{d}\right)$, as described in Equation 2. This definition is aimed at describing the loading of wastewater containing both high-strength ammonium and organic matter [38]

$$
\mathrm{ILR}=1.80 \times \mathrm{ALR}+\mathrm{CLR}
$$

The total air flux (TAF) $\left(\mathrm{m}^{3}\right.$ air $/ \mathrm{m}^{3}$ reactor $\left./ \mathrm{d}\right)$ was defined as the multiplication of AFR $\left(\mathrm{m}^{3}\right.$ air $/ \mathrm{m}^{3}$ reactor/h) and the aeration time $(\mathrm{h} / \mathrm{d})$, as described in Equation 3:

$\mathrm{TAF}=$ Aeration Time $\times$ AFR 


\section{Results and Discussion}

\section{Start-up}

In the first three weeks of start-up, nitrite accumulation did not occur, whereas significant nitrate formation and even complete nitrification in the third week were observed (Figs 1a and 1b). This undesired observation cannot be explained by the FA concentration inhibition theory proposed by Anthonisen et al. [41], since there is significant difference in microbial species, operational strategies and degree of acclimation among the studied reactors. The presence of nitrite-oxidizing bacteria (NOB) in the seed sludge from the full-scale SBR for landfill leachate treatment might be acclimated to high FA and FNA concentrations. The DO concentrations at the end of aeration stage were $0.80-1.55 \mathrm{mg} / \mathrm{L}$, which was significantly lower than the values that led to stable partial nitritation in the study by Yamamoto $\mathrm{T}$. et al. [42]. These low DO conditions, however, did not cause nitrite accumulation. A previous study showed that the adjustment of the ammonium loading rate was also effective at causing partial nitritation [43]. Taking into account the oxygen consumption due to degradation of organic matter, the adjustment of ILR was used as a controlling strategy. Then the ILR of the reactor was increased (Figs 1c and 2c) while the AFR was slightly decreased (Fig. 1c). Consequently, partial nitrite accumulation together with a gradual decline in nitrate formation was observed in the next two weeks, indicating the effectiveness of the ILR adjustment strategy. The DO concentration in the reactor was lowered to below $0.5 \mathrm{mg} / \mathrm{L}$, which may help inhibit the NOB in the reactor. At the end of the start-up, the effluent nitrite to ammonium molar ratios were in the range of 1.0-1.5 and the effluent nitrate percentages were below $5 \%$ (Fig. 1b), demonstrating the successful start-up of partial nitritation. The nitrite production rate (NPR) was low (Fig. 1c) due to the low AFR and the low ILR applied.

Both the removal efficiencies of $\mathrm{COD}$ and $\mathrm{TN}$ were as high as $60 \%$ when partial nitritation was established, indicating satisfactory simultaneous removal of organic matter and nitrogen (Fig. 2). The increase in the COD and TN loading rates (Fig. 2c) led to the development of partial nitritation; therefore, this implies the effectiveness of the adjustment of ILR to achieve PN performance. Due to a dominant nitritation reaction in the reactor, the effluent $\mathrm{pH}$ was slightly lower than
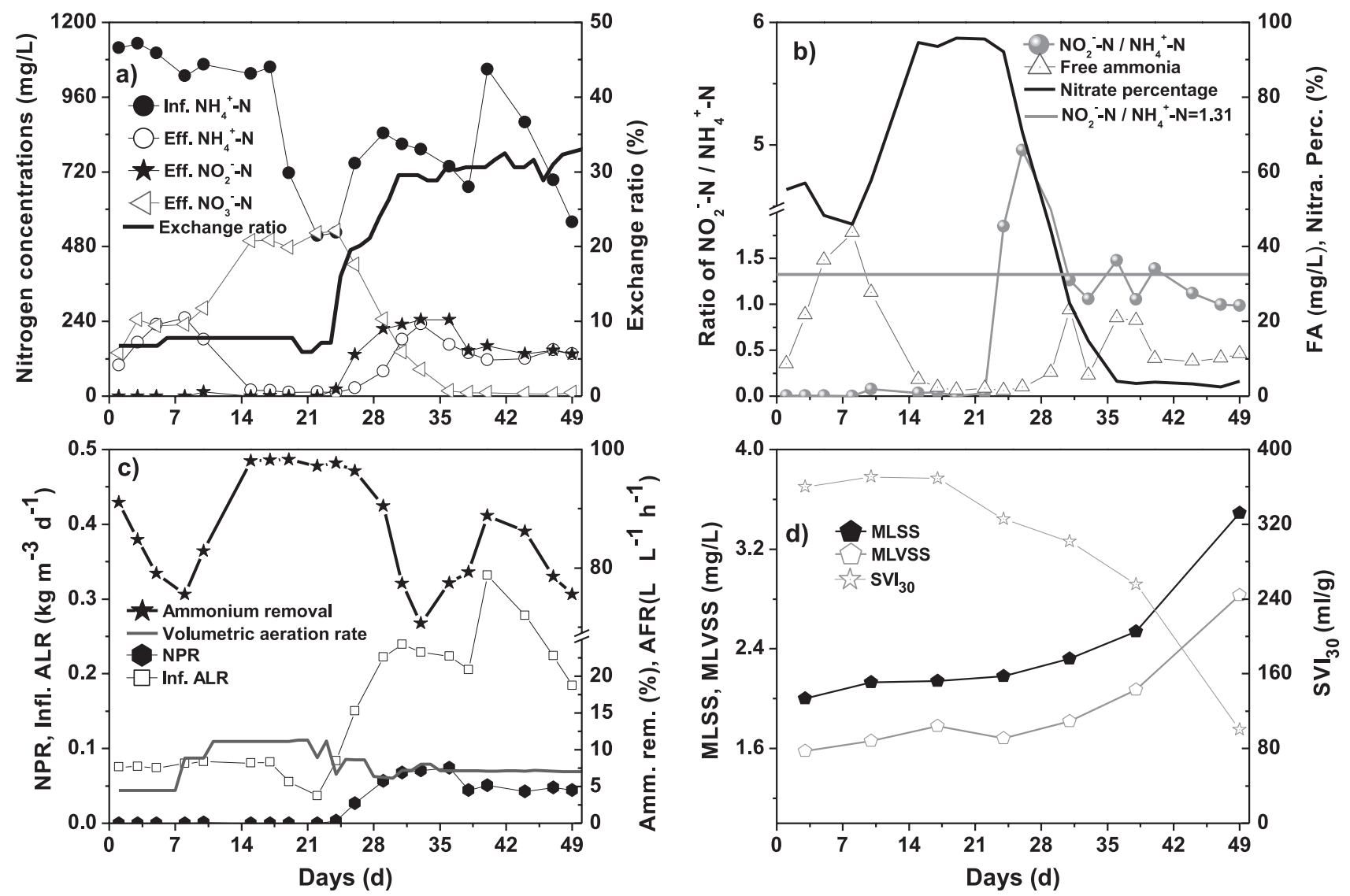

Fig. 1. PN performance of reactor during start-up period: a) influent and effluent nitrogen species and volumetric exchange ratio (VER); b) effluent molar ratio of nitrite to ammonium, and nitrate percentage (\%) and free ammonium (FA); c) ammonium removal efficiency, air flow rate (AFR), nitrite production rate (NPR) and influent volumetric ammonium loading rates (ALR); and d) concentrations of MLSS and MLVSS, and $\mathrm{SVI}_{30}$. 
the influent $\mathrm{pH}$ (Fig. 2d). The mass ratios of consumed COD to TN fluctuated when shifting from complete nitrification to partial nitritation, and then maintained at a value of approximately 3.0 (Fig. 2d). The nitrogen and organic removal in this case was responsible for the combination of heterotrophic aerobic degradation and heterotrophic denitrification, as well as the dilution effect.

\section{Operation}

After start-up, higher AFR (Fig. 3c) and larger ILR (Fig. 4c) were used in the next operating phases in order to enhance the treatment capacity. Despite the variation in the influent strength, the effluent nitrate percentage was able to be controlled below $10 \%$ (Figs $3 \mathrm{a}$ and $3 \mathrm{~b}$ ) via a corresponding controlling of AFR, and the ammonium removal efficiencies were elevated to $70-90 \%$ (Fig. 3 c). However, it should be noted that due to occasional power failure events, the effluent nitrite to ammonium molar ratios were fluctuating and in some periods were higher than 4.0 or lower than 0.5 (Fig. 3b). In addition, the float valve was easily adhered with activated sludge, leading to the change in the treatment capacity (associated to the VER, Fig. 3a). This is another cause for the variation in the effluent nitrite to ammonium molar ratio. The biomass concentration increased during these experimental phases, and the sludge settlement improved significantly, indicating a good sludge performance.

The effluent COD concentrations increased substantially from Phase 2 to Phase 4 (Fig. 4a), however, the TN removal increased slightly during Phases 3-4 when compared with those in Phase 2 (Fig. 4b). This might imply that denitrification was strengthened in Phases 3-4. The NPR appeared to be declining (Fig. 3c) when the ILR increased (Fig. 4c). This may also be attributed to the enhancement on the heterotrophic denitrification, which was supported by the concurrent increase in the COD and TN removal efficiencies (Figs $4 \mathrm{a}$ and $4 \mathrm{~b}$ ) and in the effluent $\mathrm{pH}$ as well as in the consumed $\mathrm{C} / \mathrm{N}$ (Fig. 4d). It should be noted that a long SRT could cause a low activity of the bacteria. However, as shown in Fig. 4c), the highest nitrogen removal rate and COD removal rate reached $0.4 \mathrm{~kg} \mathrm{~N} / \mathrm{m}^{3} / \mathrm{d}$ and $2.4 \mathrm{~kg} \mathrm{COD} / \mathrm{m}^{3} / \mathrm{d}$, respectively. Therefore, by means of proper control, the bacteria activity and loading rate can still be high regardless of SRT.
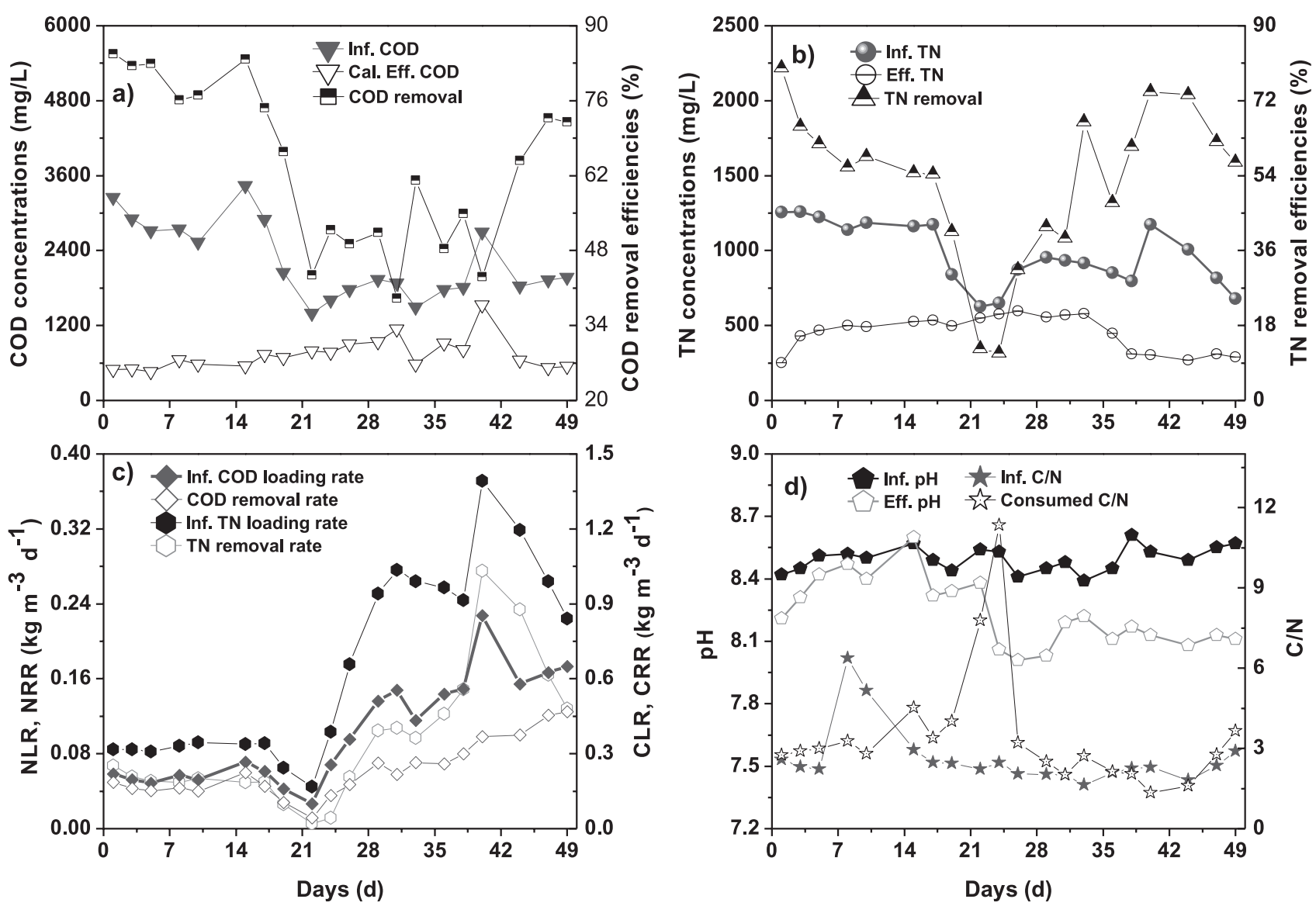

Fig. 2. Performance of reactor during start-up period: a) influent and effluent COD concentrations and COD removal efficiencies; b) influent and effluent TN concentrations and TN removal efficiencies; c) influent COD loading rate (CLR) and COD removal rate (CRR), influent TN loading rate (NLR) and TN removal rate (NRR); and d) influent and effluent $\mathrm{pH}$, and influent $\mathrm{C} / \mathrm{N}$ and consumed $\mathrm{C} / \mathrm{N}$. 


\section{Cycle Analysis}

To better understand the state of the reactor, cycle analysis of the nitrogen species evolution dynamics and COD concentrations on day 164 was conducted (Fig. 5). In the feeding stage, concentrations of ammonium, TN, COD, alkalinity and FA, as well as $\mathrm{pH}$ in the reactor, increased due to the feeding event. In the first anoxic stage (0-90 min), the DO concentrations were below $0.2 \mathrm{mg} / \mathrm{L}$. Approximately $135 \mathrm{mg} / \mathrm{L}$ nitrite and $9 \mathrm{mg} / \mathrm{L}$ nitrate were denitrified, resulting in a substantial increase in $\mathrm{pH}$ and alkalinity. The actual consumption of COD (approximately $440 \mathrm{mg} / \mathrm{L} \mathrm{COD)}$ was more than the theoretical value $(257 \mathrm{mg} / \mathrm{L})$ derived from the nitrogen loss caused by denitrification, which may be attributed to the anabolism and biosorption effects [21].

During the first aeration stage (91-360 min), low DO concentrations (below $0.6 \mathrm{mg} / \mathrm{L}$ ) were observed. Around $63 \mathrm{mg} / \mathrm{L}$ nitrite was produced, while around $121 \mathrm{mg} / \mathrm{L}$ ammonium and $6 \mathrm{mg} / \mathrm{L}$ nitrate were consumed. The stripping of ammonia by aeration might contribute to some loss of ammonium; however, little literature on this aspect was available, and the quantitative determination of this effect was difficult. Therefore, this effect might be negligible under these low DO conditions. The reduction of nitrate during this stage did verify that the denitrification occurred in the reactor. Consequently, there is an indication of the occurrence of simultaneous nitritation and denitrification in the reactor. The anoxic condition in this stage might make the simultaneous nitritation and denitrification possible. However, the partial nitritation was the dominant reaction, since there was an obvious decline in $\mathrm{pH}$ and in alkalinity recorded. This conclusion was supported by the increase in nitrite and the decrease in ammonium. The low DO conditions and high levels of FA $(42-110 \mathrm{mg} / \mathrm{L})$ may be the main inhibitors for nitrite oxidation bacteria (NOB).

In the second anoxic stage (361-420 min), the DO concentrations were below $0.05 \mathrm{mg} / \mathrm{L}$, which is a classic anoxic condition for denitrification. The $\mathrm{pH}$ increased slightly, as well as approximately $12 \mathrm{mg} / \mathrm{L}$ nitrite, $2 \mathrm{mg} / \mathrm{L}$ nitrate, and $60 \mathrm{mg} / \mathrm{L}$ COD were removed, indicating the occurrence of denitrification reaction. Similar to the first anoxic stage, the actual consumption of COD was more than the theoretical value derived from the nitrogen loss. This may be attributed to the other reactions such as anabolism and biosorption, which
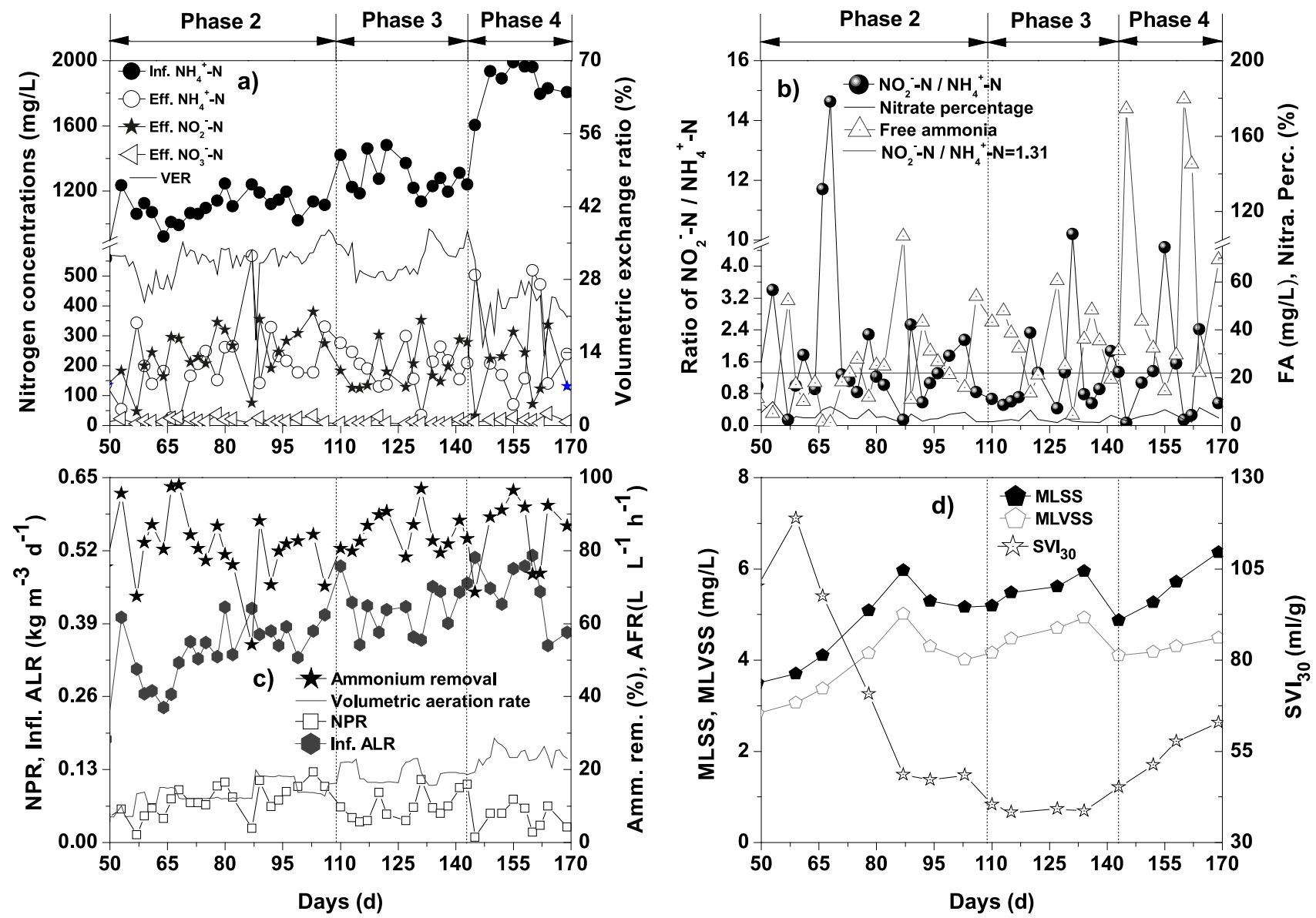

Fig. 3. PN performance of reactor during operation period: a) influent and effluent nitrogen species and volumetric exchange ratio (VER); b) effluent molar ratio of nitrite to ammonium, and nitrate percentage and free ammonium (FA); c) ammonium removal efficiency, air flow rate (AFR), nitrite production rate (NPR) and influent volumetric ammonium loading rates (ALR); and d) concentrations of MLSS and MLVSS, and $\mathrm{SVI}_{30}$. 
likely occurred throughout the bioprocess. The nitrogen and COD loss in this stage were much less than those in the first anoxic stage, which is possibly due to the lower availability of organic matter for denitrification.

In the second aeration stage (421-660 min), the DO concentrations were at the range of $0.30-0.80 \mathrm{mg} / \mathrm{L}$ - slightly higher than those in the first aeration phase. The decline in $\mathrm{pH}$ and alkalinity and the measured $\mathrm{NO}_{2}^{-}-\mathrm{N}$ accumulation suggested the nitritation reaction. During this stage, $92 \mathrm{mg} / \mathrm{L} \mathrm{NO}_{2}^{-}-\mathrm{N}$ and $16 \mathrm{mg} / \mathrm{L}$ $\mathrm{NO}_{3}{ }^{-} \mathrm{N}$ were produced, while $93 \mathrm{mg} / \mathrm{L} \mathrm{NH}_{4}{ }^{-} \mathrm{N}$ was removed, indicating that some organic nitrogen might be converted to $\mathrm{NH}_{4}^{+}-\mathrm{N}$ since the $\mathrm{TN}$ concentrations did not decrease. Similarly, heterotrophic denitrification and stripping of ammonia were negligible because the TN concentrations did not decline during this stage. Although an insignificant formation of $\mathrm{NO}_{3}^{-}-\mathrm{N}$ occurred, it ceased in the latter part of this stage. Therefore, partial nitritation was the dominant reaction in this stage. The weak nitritation observed was likely due to the FA levels decreasing, which inhibited the NOB activity. The increase in FNA to $0.008 \mathrm{mg} / \mathrm{L}$ (Fig. 5c) might be an inhibitor for NOB in this phase. The reported FNA level at $0.01-0.025 \mathrm{mg} / \mathrm{L}$ [43] did not inhibit NOB, and the main cause of the low NOB activity may be due to the FA inhibition.

At the settling stage, no measurable change caused by bioreaction was observed. During the entire cycle, heterotrophic denitrification contributed to approximately $28 \%$ of nitrogen and $24 \%$ of COD in the bulk liquid in the reactor, indicating the successful combination of denitrification and partial nitritation in a single reactor. Simultaneous nitritation and denitrification were interestingly found in the first aeration stage but not in the second one, which was likely caused by the higher DO concentrations in this stage. In a test conducted for the treatment of landfill leachate by Ganigue et al. [32], frequent alternating feeding and aerating regimes, in combination with a reaction temperature of $36 \pm 1^{\circ} \mathrm{C}$ and a SRT of $9.0 \pm 1.5$ days used, achieved a reduction of approximately $200 \mathrm{mg} / \mathrm{L}$ nitrogen, which was mainly due to denitrification. In this study, comparable performance was able to be achieved by using the lower reaction temperatures of $24.5-27.0^{\circ} \mathrm{C}$ and the longer SRT of 60-80 days.
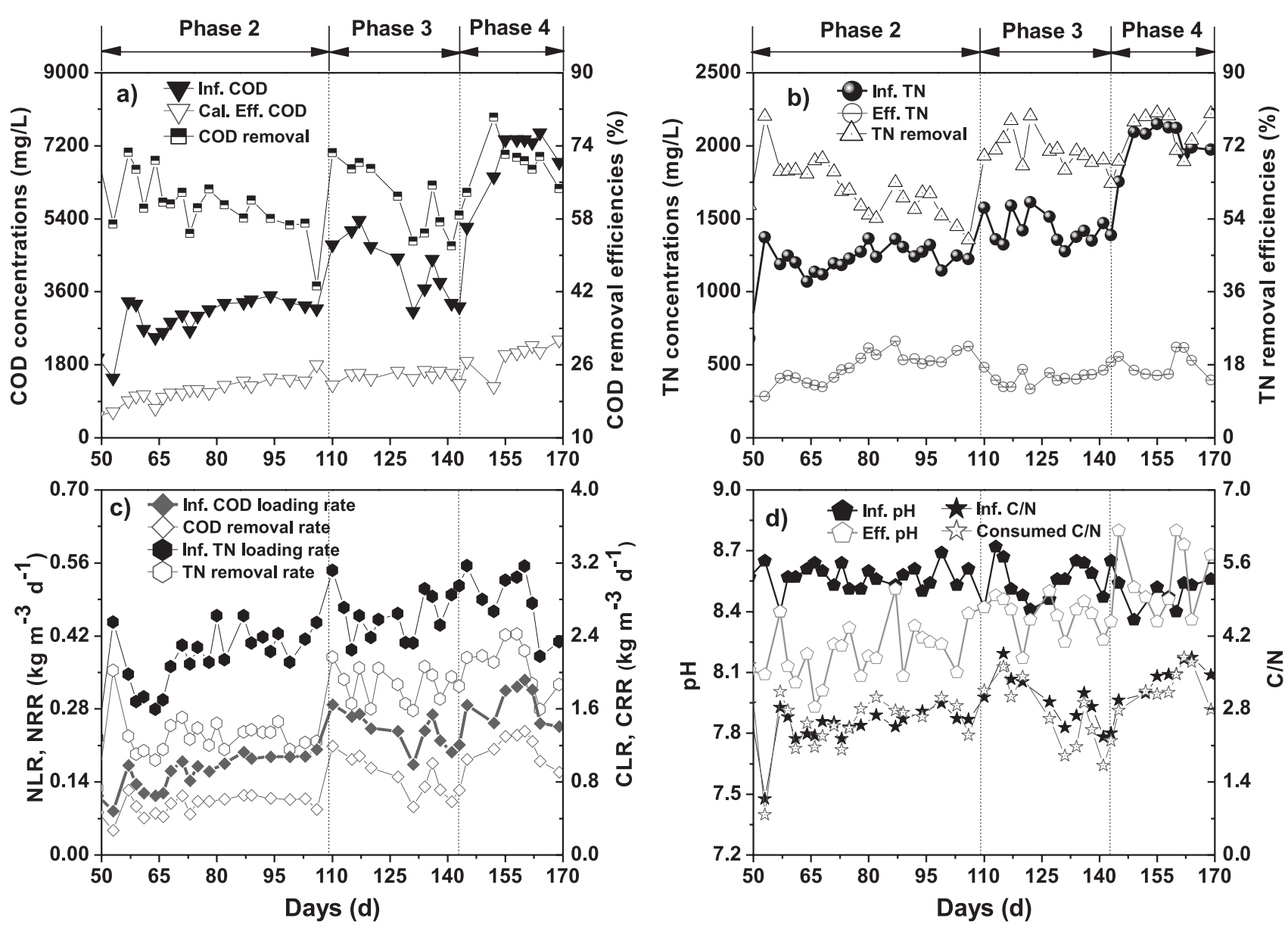

Fig. 4. Performance of reactor during operation period: a) influent and effluent COD concentrations and COD removal efficiencies; b) influent and effluent TN concentrations and TN removal efficiencies; c) influent COD loading rate (CLR) and COD removal rate (CRR), influent TN loading rate (NLR) and TN removal rate (NRR); and d) influent and effluent $\mathrm{pH}$, and influent $\mathrm{C} / \mathrm{N}$ and consumed $\mathrm{C} / \mathrm{N}$. 

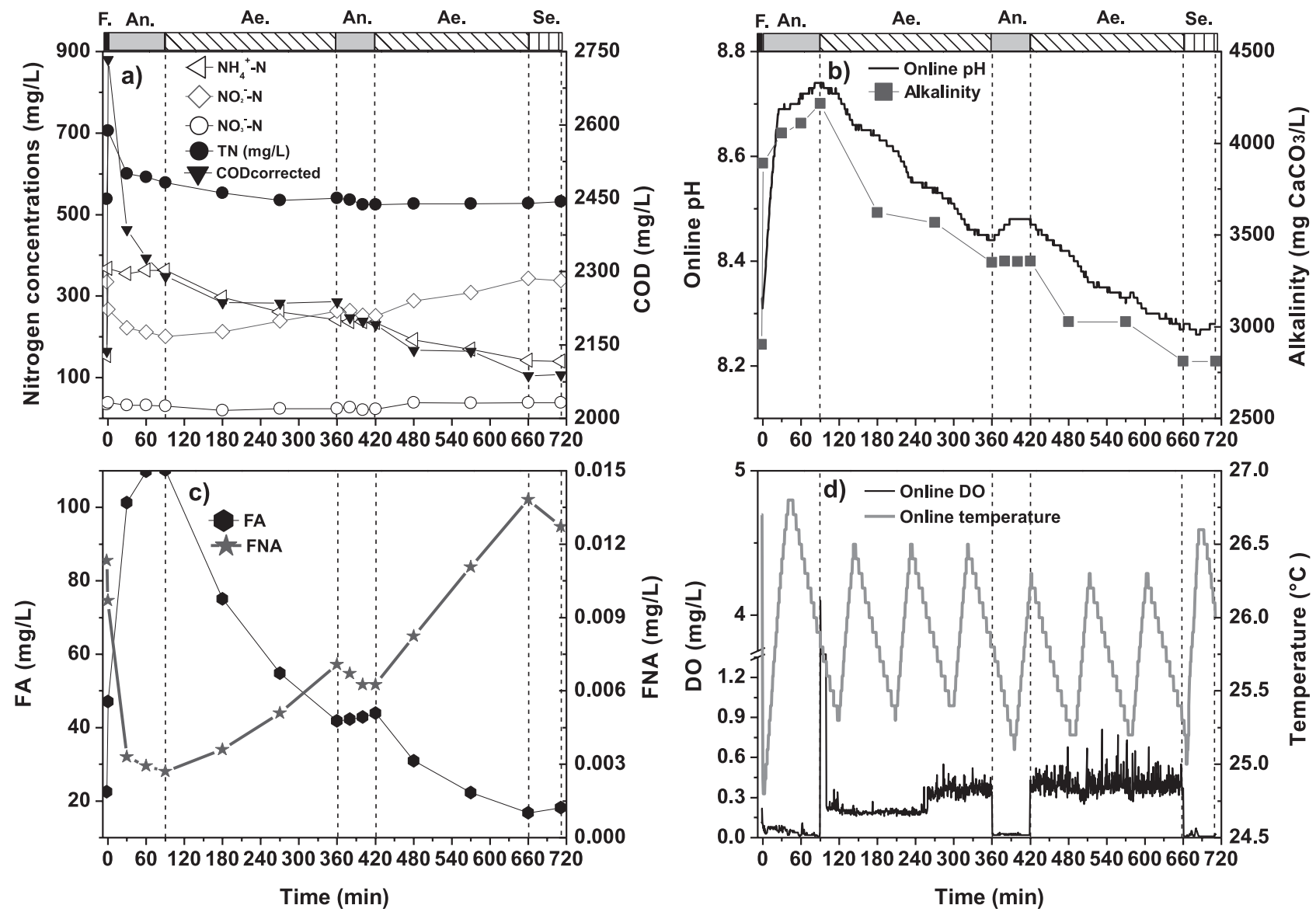

Fig. 5. Cycle analysis in the bulk liquid in the reactor on day 164: a) concentrations of nitrogen species and COD; b) online pH, alkalinity; c) concentrations of FA and FNA; and d) online DO concentrations and temperatures (F: Feed; An: anoxic stage; Ae: Aeration stage; Se: settling stage).

\section{Process Analysis}

\section{Effect of TAF on COD Removal rate (CRR) and Nitrogen Removal Rate (NRR)}

The most direct controlling factor, TAF, might have a significant link with the oxygen (or DO) demand for the aerobic degradation of organic matter and partial nitritation. Therefore, the effect of TAF on CRR and NRR was evaluated. Both NRR and CRR could be described as the functions of TAF (Eqs 4-5 and Fig. 6). The utilization of a larger TAF resulted in higher NRR and CRR being achieved, since the higher loading rate undoubtedly requires a greater oxygen supply. It should be noted that the variation in the influent conditions and the corresponding change in AFR, as well as the removal of organic matter through denitrification, might lead to some deviation in the models. However, these models obtained from the long-term operation would be useful for the rough evaluation of TAF needed during the operation.

$$
\begin{aligned}
\mathrm{CRR}= & -0.02612+0.00223 \times \mathrm{TAF} \\
& +1.56961 \mathrm{E}-6 \times \mathrm{TAF}^{2}
\end{aligned}
$$
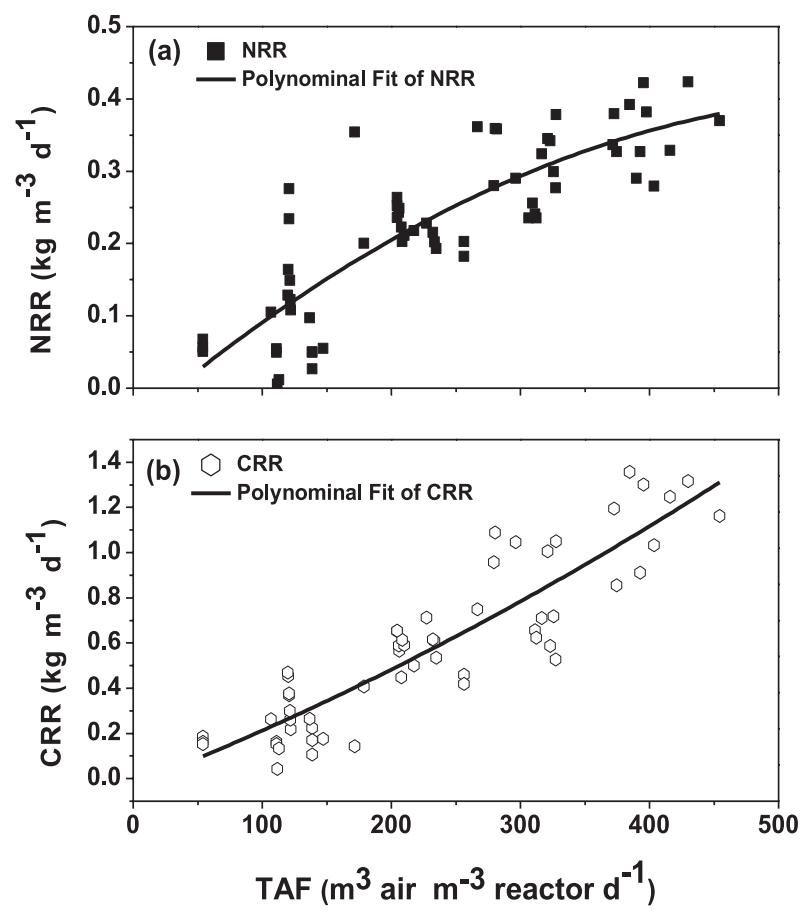

Fig. 6. Effect of TAF on COD (CRR) and nitrogen (NRR) removal rates. 


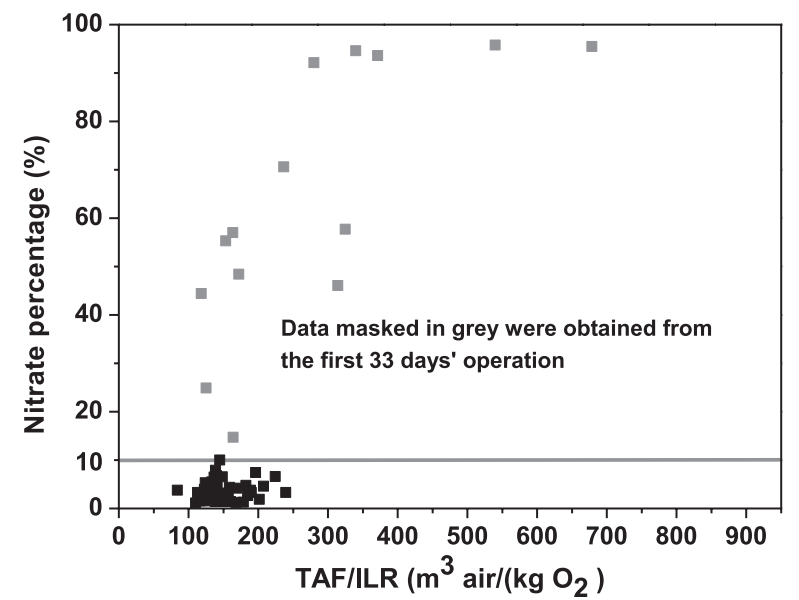

Fig. 7. Relationship between effluent nitrate percentage and the ratio of TAF/ILR.

$$
\begin{aligned}
\mathrm{NRR} & =-0.04897+0.00153 \times \mathrm{TAF} \\
& -1.28592 \mathrm{E}-6 \times \mathrm{TAF}^{2}
\end{aligned}
$$

\section{Effect of TAF/ILR on Effluent Nitrate Percentage}

The presence of high concentrations of organic matter can affect the partial nitritation performance, since the aerobic degradation of organic matter also requires oxygen. In order to avoid the excess or lack of oxygen supply, organic loading must be taken into account. The evaluation of the effect of TAF/ILR on the effluent $\mathrm{NO}_{3}^{-}-\mathrm{N}$ percentage may be useful for judging the requirement of air supply in terms of the ILR. During the first 33 days of operation, $\mathrm{NO}_{3}^{-}-\mathrm{N}$ formation was gradually inhibited when the ratio of TAF/ILR decreased from 678 to $118 \mathrm{~m}^{3}$ air $/ \mathrm{kg}$ COD, as shown in Fig. 7. After start-up, the effluent $\mathrm{NO}_{3}^{-}-\mathrm{N}$ percentage was below $10 \%$ when the ratio of TAF/ILR was controlled at $85-240 \mathrm{~m}^{3}$ air $/ \mathrm{kg}$ COD. For this system, the threshold of the ratio of TAF/ILR leading to successful partial nitritation with negligible nitrate formation was less than $240 \mathrm{~m}^{3}$ air $/ \mathrm{kg}$ COD. A previous study showed that the ratio of TAF/ILR in a similar range of $163-256 \mathrm{~m}^{3}$ air $/ \mathrm{kg}$ COD was also effective for stably maintaining an effluent $\mathrm{NO}_{3}^{-}-\mathrm{N}$ percentage below $13 \%$ for an intermittent column SBR [38]. It should be stressed that differences in the reactor configuration and in aeration strategy as well as in the wastewater type might result in different threshold levels for successful partial nitritation. The DO control is a widely used strategy to maintain nitritation, because the DO could be easily controlled through the adjustment of aeration [9]. In fact, the mechanism behind both the DO and the airflow rate control is the same, namely the air supply must match influent loading, including nitrogen and organic loadings [44].
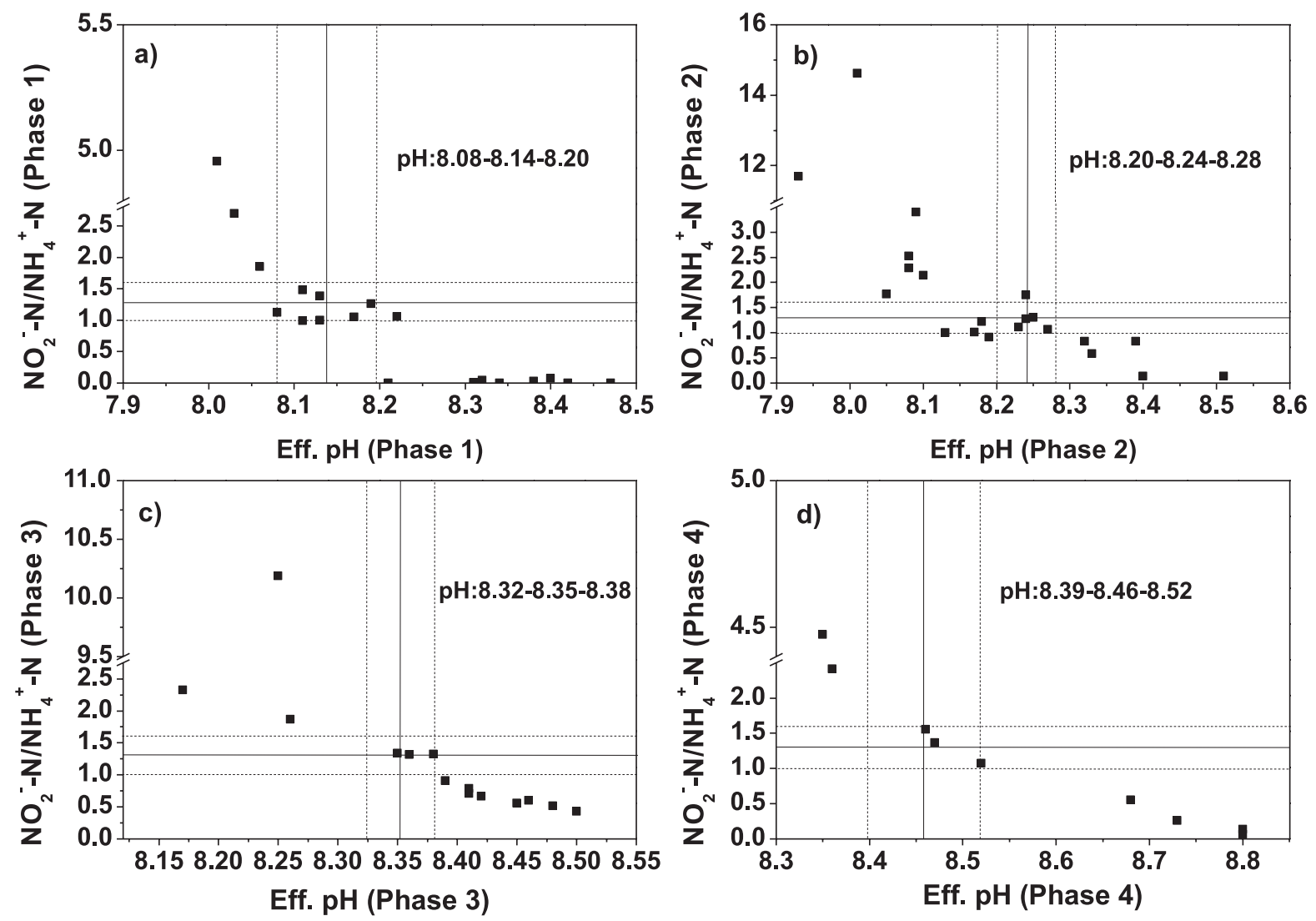

Fig. 8. Relationship between effluent $\mathrm{pH}$ and effluent $\mathrm{NO}_{2}{ }^{-}-\mathrm{N} / \mathrm{NH}_{4}{ }^{+}-\mathrm{N}$ ratio ratio (adequate effluent $\mathrm{NO}_{2}{ }^{-}-\mathrm{N}^{-} \mathrm{NH}_{4}{ }^{+}-\mathrm{N}$ ratio defined herein was 1.0-1.6) . 


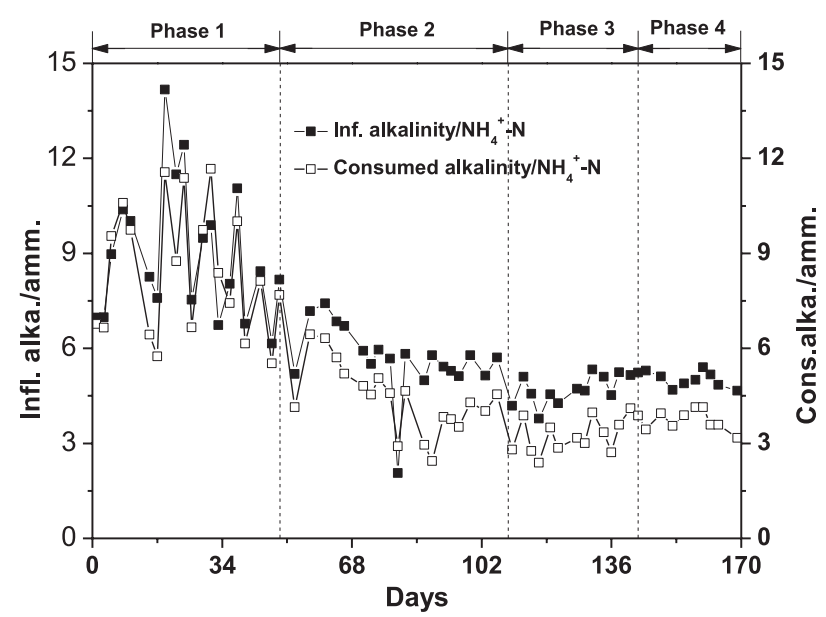

Fig. S1. Evolution of inf. alkalinity $/ \mathrm{NH}_{4}^{+}{ }^{+} \mathrm{N}$. and consumed alkalinity/ $\mathrm{NH}_{4}^{+}-\mathrm{N}$ during the operational periods.

Relationship between Effluent $\mathrm{pH}$ and Effluent $\mathrm{NO}_{2}-\mathrm{-} / \mathrm{NH}_{4}{ }^{+}-\mathrm{N}$ Ratio

In addition to the avoidance of $\mathrm{NO}_{3}^{-}-\mathrm{N}$ formation, the maintenance of a suitable effluent $\mathrm{NO}_{2}^{-}-\mathrm{N}^{-} \mathrm{NH}_{4}{ }^{+} \mathrm{N}$ ratio around 1.32 is the other requirement for the $\mathrm{PN}$ process. The level of effluent $\mathrm{pH}$ was determined to be significantly associated with the partial nitritation performance under different influent compositions (Fig. 8). The optimum effluent $\mathrm{pH}$ levels estimated in Phases 1-4 were 8.08-8.20, 8.20-8.28, 8.32-8.38 and 8.39-8.51, respectively. There is a clear increasing tendency of the effluent $\mathrm{pH}$ when the ILR applied was increasing. Therefore, the effluent $\mathrm{pH}$ can be an indicator of partial nitritation performance. The $\mathrm{pH}$ in the effluent with a suitable effluent $\mathrm{NO}_{2}^{-}-\mathrm{N}^{-} \mathrm{NH}_{4}{ }^{+} \mathrm{N}$ ratio was relatively low when dealing with low loaded leachate, while a higher $\mathrm{pH}$ level was observed when dealing with a higher loaded leachate [38]. This is probably owing to the improvement in heterotrophic denitrification and mineralization of organic carbon (strengthening $\mathrm{CO}_{2}$ stripping effect) when the treatment capacity was increased. The observation that the consumed mass ratio of alkalinity/ $\mathrm{NH}_{4}{ }^{+} \mathrm{N}$ was always lower than the influent mass ratio of alkalinity $/ \mathrm{NH}_{4}{ }^{+}-\mathrm{N}$ (influent alkalinity $/ \mathrm{NH}_{4}{ }^{+} \mathrm{N}$ ), provided evidence for this explanation (Fig. S1) since heterotrophic denitrification produces alkalinity. In conclusion, this relationship between effluent $\mathrm{pH}$ and effluent $\mathrm{NO}_{2}-\mathrm{-} / \mathrm{NH}_{4}{ }^{+} \mathrm{N}$ ratio could be used as one of the potential indicators to develop an auto-controlled PN system.

\section{Conclusions}

At temperatures $24.5-27.0^{\circ} \mathrm{C}$ and an SRT of 60 80 days, the combination of partial nitritation and heterotrophic denitrification can be achieved by adjusting the AFR and ILR. Variation in the ILR affected the effluent $\mathrm{NO}_{2}^{-}-\mathrm{N} / \mathrm{NH}_{4}{ }^{+}-\mathrm{N}$ ratio; the timely adjustment of AFR was required to maintain the partial nitritation performance. Cyclic analysis showed that heterotrophic denitrification during the anoxic stage contributed to an approximate $28 \%$ loss of nitrogen and $24 \%$ reduction of COD in the bulk liquid. Simultaneous nitritation and denitrification occurred in the initial part of the first aeration stage. Both NRR and CRR can be described as the quadratic functions of TAF. In addition, it was observed that nitrate formation could be avoided by controlling the ratio of TAF/ILR below $240\left(\mathrm{~m}^{3} \mathrm{air} /(\mathrm{kg}\right.$ COD$)$. Lastly, the $\mathrm{pH}$ in the effluent increased with the increase in influent loading rates; therefore, the effluent $\mathrm{pH}$ can be an indicator of partial nitritation performance.

\section{Acknowledgements}

This study was supported by the Ministry of Science and Technology of China for State Key Research and Development Project (2016YFC0400702) and the Department of Science and Technology of Guizhou Province ([2018] 4005, [2019] 2957). The authors acknowledge heartfelt appreciation to all the staff members of the Solid Waste Disposal Co. Ltd. of Jiangmen City for providing lab access and their kind assistance in experimental activities.

\section{Conflict of Interest}

The authors declare no conflict of interest.

\section{References}

1. LI H.S., ZHOU S.Q., MA W.H., HUANG P.F., HUANG G.T., QIN Y.J., XU B., OUYANG H. Long-term performance and microbial ecology of a two-stage PNANAMMOX process treating mature landfill leachate. Bioresour Technol. 159, 404, 2014.

2. ZHANG F., PENG Y., MIAO L., WANG Z., WANG S., LI B. A novel simultaneous partial nitrification Anammox and denitrification (SNAD) with intermittent aeration for cost-effective nitrogen removal from mature landfill leachate. Chem Eng J. 313, 619, 2017.

3. RENOU S., GIVAUDAN J.G., POULAIN S., DIRASSOUYAN F., MOULIN P. Landfill leachate treatment: Review and opportunity. J Hazard Mater. 150 (3), 468, 2008.

4. SUN H., PENG Y., SHI X. Advanced treatment of landfill leachate using anaerobic-aerobic process: Organic removal by simultaneous denitritation and methanogenesis and nitrogen removal via nitrite. Bioresour Technol. 177, 337, 2015.

5. VEYS P., VANDEWEYER H., AUDENAERT, W., MONBALLIU A., DEJANS P., JOOKEN E., DUMOULIN A., MEESSCHAERT B.D., VAN HULLE, S.W.H. Performance analysis and optimization of autotrophic nitrogen removal in different reactor configurations: a modelling study. Environ Technol. 31 (12), 1311, 2010. 
6. GABARR J., GONZ LEZ-C RCAMO P., RUSCALLEDA M., GANIGU R., GICH F., BALAGUER M.D., COLPRIM, J. Anoxic phases are the main $\mathrm{N}_{2} \mathrm{O}$ contributor in partial nitritation reactors treating high nitrogen loads with alternate aeration. Bioresour Technol. 163, 92, 2014.

7. JETTEN M.S.M., STROUS M., VAN DE PASSCHOONEN K.T., SCHALK J., VAN DONGEN U.G.J.M., VAN DE GRAAF A.A., LOGEMANN S., MUYZER G., VAN LOOSDRECHT M.C.M., KUENEN J.G. The anaerobic oxidation of ammonium. FEMS Microbiol Rev. 22 (5), 421, 1998.

8. HE Y., ZHOU G., HUANG M., TONG M. Assessment of Inocula and N-removal Performance of Anaerobic Ammonium Oxidation (ANAMMOX) for the Treatment of Aged Landfill Leachates. In: Iranpour R, Zhao J, Wang A, Yang FL, Li X, editors. Advances in Environmental Science and Engineering, Pts 1-6. Advanced Materials Research. 518-5232012. p. 2391.

9. TROJANOWICZ K., PLAZA E., TRELA J. Pilot scale studies on nitritation-anammox process for mainstream wastewater at low temperature. Water Sci Technol. 73 (4), 761, 2016.

10. JAROSZYNSKI L.W., OLESZKIEWICZ J.A. Autotrophic ammonium removal from reject water: partial nitrification and anammox in one-reactor versus two-reactor systems. Environ Technol. 32 (3-4), 289, 2011.

11. ZHANG T., YAN Q.M., YE L. Autotrophic biological nitrogen removal from saline wastewater under low DO. J Chem Technol Biotechnol. 85 (10), 1340, 2010.

12. LI Y., LI, J., ZHAO B., WANG X., ZHANG Y., WEI J., BIAN W. A coupled system of half-nitritation and ANAMMOX for mature landfill leachate nitrogen removal. Environ Technol. 38 (18), 2335, 2017.

13. LI B., ZHANG W., YAN X., HUANG X., LI J., LI Y. Startup and Performance Stability of a NitritationAnammox Reactor Using Granular Sludge. Polish Journal of Environmental Studies. 26 (1), 173, 2017.

14. GANIGUE R., VOLCKE E.I.P., PUIG S., BALAGUER M.D., COLPRIM J. Impact of influent characteristics on a partial nitritation SBR treating high nitrogen loaded wastewater. Bioresour Technol. 111, 62, 2012.

15. ZHU W., ZHANG P., YU D., DONG H., LI J. Nitrogen removal performance of anaerobic ammonia oxidation (ANAMMOX) in presence of organic matter. Biodegradation. 28 (2), 159, 2017.

16. HU Z., LOTTI T., LOOSDRECHT M., KARTAL B. Nitrogen removal with the anaerobic ammonium oxidation process. Biotechnol Lett. 1, 2013.

17. TERADA A., ZHOU S., HOSOMI M. Presence and detection of anaerobic ammonium-oxidizing (anammox) bacteria and appraisal of anammox process for highstrength nitrogenous wastewater treatment: a review. Clean Technologies and Environmental Policy. 1, 2011.

18. ALI M., SHAW D.R., ZHANG L., HAROON M.F., NARITA Y., EMWAS A.-H., SAIKALY P.E., OKABE S. Aggregation ability of three phylogenetically distant anammox bacterial species. Water Res. 143, 10, 2018.

19. VAN LOOSDRECHT M.C.M. Innovative nitrogen removal. In: Henze M, van Loosdrecht MCM, Ekama GA, D B, editors. Biological wastewater treatment: principles, modelling and design. London: IWA Publishing; 139, 2008.

20. DU R., PENG Y., CAO S., WANG S., WU C. Advanced nitrogen removal from wastewater by combining anammox with partial denitrification. Bioresour Technol. 179, 497, 2015.

21. LI H., ZHOU S., HUANG G., XU B. Achieving stable partial nitritation using endpoint $\mathrm{pH}$ control in an SBR treating landfill leachate. Process Saf Environ Prot. 2013.

22. GABARR J., GANIGU R., GICH F., RUSCALLEDA M., BALAGUER M.D., COLPRIM J. Effect of temperature on AOB activity of a partial nitritation SBR treating landfill leachate with extremely high nitrogen concentration. Bioresour Technol. 126 (0), 283, 2012.

23. LIANG Z., HAN Z., YANG S., LIANG X., DU P., LIU G., YANG Y. A control strategy of partial nitritation in a fixed bed bioflim reactor. Bioresour Technol. 102 (2), 710, 2011.

24. ISANTA E., REINO C., CARRERA J., P REZ J. Stable partial nitritation for low-strength wastewater at low temperature in an aerobic granular reactor. Water Res. 80, 149, 2015.

25. POOT V., HOEKSTRA M., GELEIJNSE M.A.A., VAN LOOSDRECHT M.C.M., P REZ J. Effects of the residual ammonium concentration on NOB repression during partial nitritation with granular sludge. Water Res. 106, $518,2016$.

26. QIAO S., YAMAMOTO T., MISAKA M., ISAKA K., SUMINO T., BHATTI Z., FURUKAWA K. Highrate nitrogen removal from livestock manure digester liquor by combined partial nitritation-anammox process. Biodegradation. 21 (1), 11, 2010.

27. YAMAMOTO T., WAKAMATSU S., QIAO S., HIRA D., FUJII T., FURUKAWA K. Partial nitritation and anammox of a livestock manure digester liquor and analysis of its microbial community. Bioresour Technol. 102 (3), 2342, 2011.

28. QIAO S., KAWAKUBO Y., KOYAMA T., FURUKAWA K. Partial Nitritation of Raw Anaerobic Sludge Digester Liquor by Swim-Bed and Swim-Bed Activated Sludge Processes and Comparison of Their Sludge Characteristics. J Biosci Bioeng. 106 (5), 433, 2008.

29. SCAGLIONE D., FICARA E., CORBELLINI V., TORNOTTI G., TELI A., CANZIANI R., MALPEI F. Autotrophic nitrogen removal by a two-step SBR process applied to mixed agro-digestate. Bioresour Technol. 176, 98, 2015.

30. DE GRAAFF M.S., TEMMINK H., ZEEMAN G., VAN LOOSDRECHT M.C.M., BUISMAN C.J.N. Autotrophic nitrogen removal from black water: Calcium addition as a requirement for settleability. Water Res. 45 (1), 63, 2011.

31. SHINOHARA T., QIAO S., YAMAMOTO T., NISHIYAMA T., FUJII T., KAIHO T., BHATTI Z., FURUKAWA K. Partial nitritation treatment of underground brine waste with high ammonium and salt content. J Biosci Bioeng. 108 (4), 330, 2009.

32. GANIGUE R., GABARRO J., LOPEZ H., RUSCALLEDA M., BALAGUER M.D., COLPRIM J. Combining partial nitritation and heterotrophic denitritation for the treatment of landfill leachate previous to an anammox reactor. Water Sci Technol. 61 (8), 1949, 2010.

33. VILAR A., EIROA M., KENNES C., VEIGA M.C. The SHARON process in the treatment of landfill leachate. Water Sci Technol. 61 (1), 47, 2010.

34. GANIGUE R., GABARRO J., SANCHEZ-MELSIO A., RUSCALLEDA M., LOPEZ H., VILA X., COLPRIM J., BALAGUER M.D. Long-term operation of a partial nitritation pilot plant treating leachate with extremely high ammonium concentration prior to an anammox process. Bioresour Technol. 100 (23), 5624, 2009. 
35. NHAT P.T., BIEC H.N., VAN T.T.T., TUAN D.V., TRUNG N.L.H., NGHI V.T.K., DAN N.P. Stability of partial nitritation in a sequencing batch reactor fed with high ammonium strength old urban landfill leachate. Int Biodeterior Biodegrad. 124, 56, 2017.

36. CHEN Z., WANG X., YANG Y., MIRINO M.W., YUAN Y. Partial nitrification and denitrification of mature landfill leachate using a pilot-scale continuous activated sludge process at low dissolved oxygen. Bioresour Technol. 218, 580, 2016.

37. SUN H., PENG Y., WANG S., MA J. Achieving nitritation at low temperatures using free ammonia inhibition on Nitrobacter and real-time control in an SBR treating landfill leachate. Journal of Environmental Sciences. 30, 157, 2015.

38. LI H., ZHOU S., HUANG G., XU B. Partial nitritation of landfill leachate with varying influent composition under intermittent aeration conditions. Process Saf Environ Prot. 91 (4), 285, 2013.

39. LI H.S., ZHOU S.Q., SUN Y.B., FENG P., LI J.D. Advanced treatment of landfill leachate by a new combination process in a full-scale plant. J Hazard Mater. 172 (1), 408, 2009.

40. CHINA E.P.A. Standard Methods for Examination of Water and Wastewater, $4^{\text {th }}$ edition. Beijing 2002.

41. ANTHONISEN A., LOEHR R., PRAKASAM T., SRINATH, E. Inhibition of nitrification by ammonia and nitrous acid. Journal (Water Pollution Control Federation). 48 (5), 835, 1976.

42. YAMAMOTO T., TAKAKI K., KOYAMA T., FURUKAWA K. Long-term stability of partial nitritation of swine wastewater digester liquor and its subsequent treatment by Anammox. Bioresour Technol. 99 (14), 6419, 2008.

43. LIANG Z., LIU H.X. Control factors of partial nitritation for landfill leachate treatment. Journal of Environmental Sciences-China. 19 (5), 523, 2007.

44. LI H.S., ZHOU S.Q., QIN Y.J., LONG J.Y., ZHENG F.S., ZHANG H.G. Fast startup of one-stage nitritationANAMMOX reactor for high-rate nitrogen removal from mature landfill leachate. Desalination and Water Treatment. 149, 1, 2019. 